\title{
Divorce in families of children with Down Syndrome or Rett Syndrome
}

Vivian Renne Gerber Lederman ${ }^{1}$

Bianca dos Santos Alves ${ }^{1}$

Juliana Negrão Maria ${ }^{1}$

José Salomão Schwartzman ${ }^{1}$

Maria Eloisa Famá D’Antino ${ }^{1}$

Decio Brunoni ${ }^{1}$

\footnotetext{
${ }^{1}$ Programa de PósGraduação em Distúrbios do Desenvolvimento, Centro de Ciências Biológicas e da Saúde, Universidade Presbiteriana Mackenzie. R. Consolação 896/Prédio 28/1\%, Consolação. 01302907 São Paulo SP Brasil. vlederman@terra.com.br
}

\begin{abstract}
This study evaluates the impact in the stability and management of the marriage of parents of a child with Down or Rett Syndrome. Morbidity of the syndromes and the marital status of the couples before and after the birth of the affected children were considered variables. The divorce rate in families with Down syndrome was $10 \%$, similar to the Brazilian rate population. In Rett Syndrome, the divorce rate was significantly higher, 23.5\%. The higher morbidity of Rett Syndrome, and the moment of diagnosis could be relevant factors for the increased divorce rate related to this syndrome.
\end{abstract}

Key words Rett syndrome, Down syndrome, Family, Divorce 


\section{Introduction}

The birth of a baby is a fact laden with specific psychological repercussions, demanding a certain rearrangement of family dynamics ${ }^{1}$. The presence of a disabled child in the family is an additional motive for marital tension ${ }^{2}$. Before the birth of a disabled child, the family faces the loss of an ideal child, requiring them to experience this grief in order to accept this real child ${ }^{3,4}$. The family's reactions towards the disabled child and the interpretation of this deficiency reflect their own socio-historical context ${ }^{5}$. The family's acknowledgement that their child has learning disabilities displays the beginning of a path that can bring challenges along with rewards ${ }^{6}$. The adjustment process to this new situation presents the family with boththe opportunity for growth, maturation, and fortification, as well as the danger of deviations from their family members and ties ${ }^{7}$.

Down syndrome (DS) is a genetic syndrome with frequent mental disability and is caused by trisomy of chromosome 21. In most cases, the diagnosis is made at birth. The classic morphological phenotype of DSenables this recognition. Thus, it can be said that the parents of a child with DS already know that the child will be born with the condition or will have the confirmed diagnosis in the neonatal period ${ }^{8}$. Morbidity is represented by changes in cardiovascular, respiratory, endocrine, eye, ear, gastrointestinal, sleep disorder, premature aging, amongothers'. Nevertheless, survival, quality of life, and the social and educational inclusion of children with DS has significantly increased ${ }^{10}$.

Rett syndrome (RS) is a genetic syndrome caused by a mutation,predominantly in the $\mathrm{MeCP} 2$ gene located on the $\mathrm{X}$ chromosome, following the transmission model linked to the dominant $\mathrm{X}$, and the phenotype characteristic is expressed in females ${ }^{11}$. The child's neurological and psychological development appear normal; however, between 5 to 30 months of age, developmental delay is noticeable with head growth deceleration, remarkable intellectual retardation, and the association of seizures.Then, we observe the loss of voluntary manipulation of objects, presence of stereotypies in the upper limbs, and ataxia of the trunk and gait. After a period of apparent stability, other neurological abnormalitiesappear, such as vasomotor instability, respiratory disorders, scoliosis, and epilepsy ${ }^{12,13}$. Overall, it is treated as a disease with high morbidity and mortality, high impact on the quality of life, and extremely difficult in social and educational inclusion ${ }^{14}$.
It is expected that parents of children with disabilities and special needsthroughout life have high levels of stress ${ }^{15}$. The family, as a group made of subsystems, may have its function changed by several factors such as: social support, marital adjustment, and socio-economic situation ${ }^{16}$.

Few studies in literature have reported the marital status of these families, in relation to the general population. In Brazil, there is no similar study.

This study evaluated the impact of the birth of a child with DS or RS on the stability and preservation of the marriage.

\section{Method}

Participants invited to partake in this study included 100 families of individuals with DS, who attended the Association of Parents and Friends of Intellectually Disabled People in São Paulo (APAE) with a clinically confirmed diagnosis, and 136 families of individuals with RS, registered at the Brazilian Rett Syndrome Association (ABRE-TE) in São Paulo.All of the individuals contacted agreed to participate in the study.The RScases were investigated by the ABRE-TE, and diagnostics were performed by the same physician accustomed to treating patients with this syndrome. Sixty-six of the patients included in the RS sample had confirmed mutations in the MECP2 gene. Cases with a clinical diagnosis, but negative molecularfor RS, were not included. All patients included feature the classic form of RS.

The responses were analyzed from the parents and guardians of 62 males and 38 females with DS and a mean age of 13 years (+/- 8.38). Only one male individual with RS participated in the survey, and the remaining 135 participants were female, with the mean age of 15 years $(+/-$ 9.20). There was no significant difference between the mean ages of the two syndromes. The data for DS were collected in 2008 and the RS data in 2013. All ages were updated in March 2014.

All of the individuals live with their families, and in the cases of separated couples, the individual resides with the mother. Cases where the individual resides with their father or another close relative only occurred in cases of parental death (three in DS and seven in RS). None of the individualsin the research are institutionalized.

The morbidity of each syndrome was clinically evaluated, considering the five most common complications and characteristics of each syndrome. Thus, the following were considered 
for DS: cardiac abnormality, hematologic disease, hearing impairment, thyroid problems, and seizures. RS considered the following: lack of verbal communication and mobility, presence of stereotypy, scoliosis, and seizures.The information was collected through questionnaires, specifically developed for interviews conducted in -person (with 99 mothers and one sister responsible for the individuals with DS), via telephone, or e-mail (with 127 mothers, nine fathers, three grandparents, and three sisters responsible for the individuals with RS). Besides the matters described above, only the parents were asked about the following: marital status, quality of parental relationship before the birth of the individual with the syndrome, and change in the quality of the parentalrelationship after the birth of the individual. Sisters and grandparents did not answer the questions related to the quality of the relationship of the individual's parents. The in-person and telephone interviews were conducted by twoof the authors of this study, familiar with the questionnaire. The phone interviews were conducted in an empathetic manner, where the interviewer heard the participants' stories, as well as thein-person interviews, besides the questionnaire responses. In the questionnaires that were sent and answered by email ( $15 \%$ of the total), the same researcher who conducted the phone call exchanged a sufficient number messages in each case to resolve the respondents' questions.

The marriage, divorce, and separation rates of the Brazilian population were obtained from the data presented in the 2010 Census by the Brazilian Institute of Geography and Statistics $(\mathrm{IBGE})^{17}$ and updated from the data provided by the IBGE for marriages, divorces, and separations in 2011 and 2012, from the 2010 Census. The marriage, divorce, and separationsample rateswere obtained by dividing the number of married or divorced/separated couples by the total sample of each syndrome. A descriptive analysis was performed to characterize the sample, and the chi-square test to compare proportions using a significance level of $5 \%$.

The project was approved by the both ethical review committees, Universidade Presbiteriana Mackenzie and Universidade Federal de São Paulo.

\section{Results}

Table 1 shows the marital status of parents of individuals with DS and RS. Seventy-three percent of DS parents showed a stable relationship at the time of the interview ( $42 \%$ legally married), while $65.4 \%$ of RS parents showed a stable relationship (56.6\% legally married).

The percentage of separations for DSparents was $10 \%$ and $23.5 \%$ for RS, included are those separated, with or without divorce, or in the separation process, the difference being significant.

When asked about the quality of the couple's relationship before the child's birth (Table 2), $75 \%$ of DS parents responded as excellent/good, and $68 \%$ of RS responded the same.

The parents' assessment about their relationship after the child's birth (Table 3) showed no significant differences between the two syndromes.

However, when only considering the population of divorced parents, we found that $80 \%$ of DS mothers already considered the relationship bad before the birth of the child with the syndrome, with no change afterwards. The RS situation is more complex; $41 \%$ considered the relationship bad before the birth of the affected child, and the rest considered the relationship good. Although 9\% considered that the child born with RS worsened the marital relationship.

Table 1. Marital status of Down and Rett couples.

\begin{tabular}{lrrrr}
\hline & Down & \% & Rett & \% \\
\hline Sample N $^{\circ}$ & 100 & 100 & 136 & 100 \\
Legally Married & 42 & 42 & 77 & 56.6 \\
Stable relationship & 35 & 35 & 12 & 8.8 \\
Never lived together & 7 & 7 & 7 & 5,1 \\
Unknown father $^{*}$ & 1 & 1 & 0 & 0 \\
Separated $^{*}$ & $10^{*}$ & 10 & 32 & $23.5^{*}$ \\
Deceased spouse $^{* *}$ & 5 & 5 & 8 & 5.9
\end{tabular}

"Yates' Chi-square $=6.242 ; 0.02<\mathrm{p}<0.0 .{ }^{* *}$ legally married before death.

Table 2. Marital relationship before child born with the syndrome.

\begin{tabular}{lrrrr}
\hline & Down & $\%$ & Rett & $\%$ \\
\hline Sample N $^{\circ}$ & 100 & 100 & 136 & 100 \\
Excellent & 29 & 29 & 38 & 28 \\
Good & 46 & 46 & 55 & 40 \\
Normal & 4 & 4 & 10 & 7 \\
Bad / Terrible & 16 & 16 & 12 & 9 \\
No response & 4 & 4 & 15 & 12 \\
Not applicable & 1 & 1 & 6 & 4
\end{tabular}

*Questionnaires not answered by the progenitors. 
Table 3. Marital relationship after child born with the syndrome.

\begin{tabular}{lrrrr}
\hline & Down & \% & Rett & \% \\
\hline Sample N $^{\circ}$ & 100 & 100 & 136 & 100 \\
Better & 36 & 36 & 27 & 20 \\
Worse & 21 & 21 & 29 & 21 \\
No change & 35 & 35 & 53 & 39 \\
No response & 7 & 7 & 21 & 16 \\
Not applicable $^{*}$ & 1 & 1 & 6 & 4
\end{tabular}

"Questionnaires not answered by the progenitors.

When the parents separated, the mean age of DS individuals was 17-years-old, and 19-years -old for RS individuals, with no significant difference between them.

The morbidity rate found for DS was $25.6 \%$ and $71.34 \%$ for RS. When analyzing each complication, DSindividuals presented the following: $52 \%$ with heart problems, $41 \%$ with thyroid problems, $20 \%$ with hearing problems, $9 \%$ with blood disorders, and only $6 \%$ withseizures. RS individuals demonstrated that $99 \%$ had stereotypies, $86 \%$ do not speak, $70 \%$ have scoliosis, $56 \%$ have seizures, and $45 \%$ do not walk. It is noteworthy that $22 \%$ of RS individuals have all five complications, $35 \%$ have four of the complications, and $4 \%$ have only one complication. In contrast, $42 \%$ of individuals with DS have only one complication, $26 \%$ have two complications, and only $2 \%$ have all five complications described.

\section{Discussion}

This study found a significantly different divorce rate between the two syndromes studied. In 2008 , the separation rate was $10 \%$ for couples of children with DS, comparable to the divorce and legal separation rateof $13.7 \%$ in Brazil, presented in the 2010 Census from IBGE ${ }^{17}$. On the other hand, the divorce rates collected in 2013 regarding couples with daughters with RS was $23.5 \%$, significantly higher than the rate shown in 2012 of $14.72 \%$, which was adjusted from the data provided by the IBGE of marriages, divorces and separations in 2011 and 2012, according to the 2010 Census.Previous studies have identified lower divorce rates in families that have children with DS, in relation to families that have children with other disabilities ${ }^{18,19}$ or similar rates to the general population ${ }^{20}$. Due to certain characteristics of DS itself, the term "Down Syndrome Advantage" ${ }^{21}$, as it is perceived along withits existing support, indicates that parents of children with DSare ableto cope better with the losses involved, compared to other syndromes. In our study, DS parents were more likely to answer questions related to the quality of the marital relationship before and after the birth of the child with the syndrome than the RS families, perhaps reflecting DS as a better condition to deal with.

It was also observed that $80 \%$ of the sampled DS couples considered their relationship bad before the child's birth. Although their opinions that the relationship worsened with the difficulties imposed by the child's syndrome, their marital statuspriorto the birth seems to be a determinant. This result is aligned with data found in other studies, including factors such as low-income, rural housing, low education level, and young parents, which are presented as factors related to divorce ${ }^{19}$. Since the result found in our sample was consistent with the divorce rate in the Brazilian population at the time, we can consider that the disability itself would not be the cause of divorce.

We found different situations among the RS couples that showed a significantly higher number of divorces, and in $9 \%$ of the cases, the relationship worsened after the child's birth. The high morbidity rate of $71.34 \%$ and health complications that compromise mobility and communication, in addition to the impact on clinical situations,i.e. seizures, createa strenuous family routine and certainly contribute to increased family stress. The comparison of children with RSto those with DS, when using the Functional Independence Measure instrument,presented lower rates, requiring significantly more help in all of the areas assessed ${ }^{22}$. Among the disadvantages cited in a comparative study of Australian families that have children with DS and RS, the RS group had more complaints about the restriction of family life and socialization, possibly due to the greatamount of care that the syndrome requires and the low mobility of the affected individual. Although in both groups, the greater the economic advantage, the more notablethe disadvantages of having a child with disabilities. Twelve percent of parents of children with DSpresented advantages in having a child with a disability, compared to only $6 \%$ of parents of children with $\mathrm{RS}^{8}$. Even couples that have Rett daughters and remain married, reported limited independence for their own needs and social isolation, and much of the couple's energy is spent 
on caring for the child and not the relationship. The demand for long, extensive care may contribute to the decline in marital satisfaction over the years ${ }^{14}$. The fact that all children of divorced parents remain with their mothers aligns with the discussion of Perry et al. ${ }^{15}$, that although the whole family is affected, the burden of having a disabled child falls more so on the mother, who is often responsible for their care.

One should also consider the late diagnosis of this syndrome. While the diagnosis of DS is usually announced to parents at the hospital or even during the prenatal period, RS usually manifests itself after 18 months. Parents of children with DS reported disorientation, shock, loss of an idealized situation, and anxiety about the future - primarily due to misinformation about the child's clinical condition upon diagnosis at the hospital ${ }^{23}$. In order to understand this process, we should observe that from conception, parents dream of anidealchild, and attribute him/her with every perfection and expectation to accomplish all of the desires that they could notachieve. This occurs during pregnancy and intensifies after birth. It becomes necessary to cope with the loss of the imaginary child to get in touch with the real child, especially when this idealization is so different from the conceived. Just after the birth of a baby with DS, these representations are reassessed, and the new roles should be worked on by the parents in the following months; while in RS, parents have a closer to ideal son and live this process up to 18 months, only to deconstruct it ${ }^{24-26}$.

Parents should then deal with the frustration of knowing that theirpreviously healthy child will now present a series of deficiencies, the severity of which will only be set after several years of neurological impairment. Added to this is the constant fear of losing their child due to the high mortality of the disease. The fact that the child initially appears healthy, allowing the parents to create expectations for the future, and the subsequent confrontation with the diagnosis of RS, appears to contribute to increased stress ${ }^{14}$.

The potentially negative consequences, resulting from additional stress of a child with a developmental disorder, are measured by the quality of the marital relationship before the child's diagnosis, social support, personality, beliefs, and the parents' personal abilities ${ }^{16}$. Professionals responsible for communicating the diagnosis should help make this moment less traumatic, assisting the family to overcome this stage better ${ }^{23}$. Ways to support these families may include: family counseling at the time of diagnosis about the diffi- culties and marital stress that follow, therapeutic support for parents, support from the extended family - such as grandparents, aunts, and uncles - as well as a support network in the community.

Consider that the differences presented between DS and RS couples can be attributed not only to the particular characteristics of each syndrome, in relation to the severity of the conditions, but also the more accessible conditions and opportunities of social and educational services and therapeutic support offered to the DS group. The interest group formed by parents and professionals in the Brazilian society has been constituted over time, and greater incentive to include the DS group in school and non-school spaces is now a fact. Unlike the RS group, which shows lower prevalence in the population and greater severity of the condition, including being classified as multiple disabilities, thus requiring more intense and complex care and greater dependence on the family, especially the mother.

Limitations of this study point out the lack of data regarding the timing of the divorce (how old the child with the syndrome was when it occurred, and how many years the couple had been married), age and education level of mothers, as well as the social class to which they belong. These data would supplement our findings, by allowing better definitions of the factors that contribute to the preservation or termination of the marriage, helping support the family.

Some biases could have occurred, due to the characteristics of the sample, such as the fact that among the RS couples, nine fathersresponded. The perception of fathers and mothers in relation to the relationship might be different. However, excluding the sample questionnaires of the nine fathers from the RS group and re-analyzing all of the variables, the results do not change, neither the percentage of separations nor the perception of the relationship.

Another methodological characteristic was the difference in the administration of the questionnaires. The RS group responded to the questions via email and phone, while the DS group responded in-person. We applied this method because while the children with DS were being examined, we proceeded to administer the questionnaire in-personwiththe mothers. In the RS group, we used the database of an association that assesses children from several Brazilian cities, which hindered direct contact with the parents. The possible influence generated by this approach was minimized because only one person made contact with the RS families. The interviewer, the 
first author of this article, knew the questionnaire in detail and sought to keep the conversation in a more natural manner by establishing a good relationship with the same empathy. The messages exchanged via e-mail tried to clarify all of the questions mentioned by the respondents.

All of the investigated families were offered genetic counseling. Although genetic counseling services in Brazil are insufficient, they are of good quality. They explain about the therapeutic resources available and ensure that the family understands the risks of recurrence ${ }^{27}$.
Our study points out a significant difference between divorce rates found in the two surveyed syndromes. While the divorce rate for families that have children with DS follows the rate of the Brazilian population, families that have children with RS have significantly higher rates. It is believed that what contributes to this differential is the high morbidity of RS and the time of diagnosis, starting from 18 months of age, while for DS is at birth. Family support at the time of diagnosis, which this datatakes into account, may help the families.

\section{Collaborations}

VRG Lederman and MEF D'Antino contributed of design method, Rett sample data collection, analysis and interpretation of data, writing the article; BS Alves contributed in Down sample data collection; J Negrão contributed to analysis and interpretation of data, writing the article; JS Schwartzman participed of Rett sample data collection analysis and critical review; and, D Brunoni participed of design method, Down sample data collection, analysis and interpretation of data, writing the article, critical review

\section{Acknowledgments}

We thank the participating families, the Associação de Pais e Amigos dos Excepcionais de São Paulo (APAE-SP) and the Associação Brasileira de Síndrome de Rett (ABRE-TE). 


\section{References}

1. Hidalgo M.V. Transición a la maternidad y la paternidad. In: Rodrigo MJ, Palacios J, organizadores. Família y desarrollo humano. Madrid: Alianza Editorial; 1998.

2. D'Antino MEF. A máscara e o rosto da instituição especializada: marcas que o passado abriga e o presente esconde. São Paulo: Memnon; 1998.

3. Rizzo AMPP. Psicologia em paralisia cerebral: experiência no setor de psicologia infantil da A.A.C.D. In: Souza AMC, Ferraretto I. Paralisia cerebral - Aspectos Práticos. 2a ed. São Paulo: Memnon; 2001.

4. Amaral AL. Conhecendo a Deficiência (em companhia de Hércules). São Paulo: Probel Editorial; 1995.

5. Ferguson PM. A place in the family: an historical interpretation of research on parental reactions to having a child with a disability. Journal of Special Education 2002; 36(3):124-130.

6. Mulroy S, Robertson L, Aiberti K, Leonard H, Bower C. The impact of having a sibling with an intellectual disability: parental perspectives in two disorders. J Intellect Disabil Res 2008; 52(3):216-229.

7. Nuñez LB. La familia con un hijo con discapacidad: sus conflictos vinculares. Arch Argent Pediatr 2003; 101(2):133-142.

8. Brunoni D. Alto Risco Genético: aspectos neonatais. Pediatria Moderna 1986; 21(8):415-422.

9. Schwartzman J.S. organizador. Sindrome de Down . 2a ed. São Paulo: Memnon, Mackenzie; 2003.

10. Bittles A, Bower C, Hussain R, Glasson EJ. The four ages of Down syndrome. Eur. J. Public Health 2007; 17(2):221-225.

11. Lima FT, Brunoni D, Schwartzman JS, Pozzi MC, Kok F, Juliano Y, Pereira LV. Genotype-phenotype correlation in Brazillian Rett syndrome patients. Arq Neuropsiquiatr 2009; 67(3-A):577-584.

12. Perry A. Rett syndrome: a comprehensive review of the literature. Am J Ment Retard 1991; 96(3):275-290.

13. Schwartzman J.S. Síndrome de Rett. Rev. Bras. Psiq 2003; 25(2):2-5.

14. Christodoulou J, Ho G. MECP2-Related Disorders. In: Pagon RA, Adam MP, Ardinger HH, Bird TD, Dolan CR, Fong CT, Smith RJH, Stephens K, editors. GeneReviews $^{\circledR}$ [serial on the Internet] 2001 Oct. Seattle (WA): University of Washington, Seattle; [acessado 2012 jun 28]. Disponível em: http://www.ncbi.nlm.nih.gov/books /NBK1497/

15. Perry A, Sarlo-McGarvey N, Facto DC. Stress and family functioning in parents of girls with Rett syndrome. J. Autism Dev. Disord 1992; 22(2):235-248.

16. Grisante PC, Aiello ALR. Interações familiares: observação de diferentes subsistemas em famílias com uma criança com síndrome de Down. Rev. Bras. Ed. Esp. 2012; 18(2):195-212.
17. Instituto Brasileiro de Geografia e Estatística (IBGE). 2010. [acessado 2014 fev 4]. Disponível em: http:// www.ibge.gov.br/home

18. Gath A, Gumley D. Family background of children with Down's syndrome and children with similar degree of mental retardation. Br J Psychiatry 1986; 149:161-117.

19. Urbano RC, Hodapp RM. Divorce in families of children with Down syndrome: a population-based study. Am J Ment Retard 2007; 112(4):261-274.

20. Carr J. Six weeks to twenty one years old: a longitudinal study of children with Down's syndrome and their families. J Child Psychol Psychiatry 1988; 29(4):407-431.

21. Hodapp RM, Ly TM, Fidler DJ, Ricci LA. Les stress, more rewarding: Parenting children with Down syndrome. Parenting:Science and Practice 2001; 1(4):317337.

22. Leonard H, Fute S, Leonard S, Sall M. Functional status, medical impairments and rehabilitation resources in 84 females with Rett syndrome: a snapshot across the world from the parental perspective. Disability and rehabilitation 2001; 23(3/4):107-117.

23. Cunha AMFV, Blascovi-Assis SM, Fiamenghi Júnior. GA. Impacto familiar da notícia da Síndrome de down para os pais: histórias e vidas. Cien Saude Colet 2010; 15(2):445-451.

24. Stern D. A constelação da maternidade: o panorama da psicoterapia pais/bebê. Porto Alegre: Artes Médicas; 1997.

25. Debray R. Bebês/mães em revolta. Tratamentos Psicanalíticos Conjuntos dos Desequilíbrios Psicossomáticos Precoces. Porto Alegre: Artes Médicas; 1988.

26. Maldonado M T. Psicologia da gravidez: parto e puerpério. Petrópolis: Vozes; 1985

27. Brunoni D. Aconselhamento genético. Cien Saude Colet 2002; 7(1):101-107

Article submitted 10/06/2014

Approved 16/09/2014

Final version submitted 18/09/2014 
Ciência \& Saúde Coletiva

volume 20 número 5 - 2015

p. 1363

onde se lê:

Juliana Negrão Maria

leia-se:

Juliana Negrão

p. 1618,

onde se lê:

require, allow understanding their perspective through stimulate a meaningful

leia-se:

which allow understanding their perspective through stimulating

p. 1622,

onde se lê:

these, the consumption

leia-se:

these figuring the consumption

p. 1626,

leia-se:

\section{Acknowledgments}

We thank the Fondo Sectorial de Investigación en Salud y Seguridad Social from the Consejo Nacional de Ciencia y Technología (CONACyT) in Mexico for their financial support through the project SALUD-142064. We thank the Deutscher Akademischer Austausch Dienst (DAAD) in Germany for providing funding for the research. Furthermore, we thank all the adolescents who participated in the project.
Ciência \& Saúde Coletiva

volume 20 número 7 - 2015

p. 2105

onde se lê/which reads:

Lívia Amaral Schumann

leia-se/reads up:

Lívia Rejane Miguel Amaral Schumann

p. 2016, 2108, 2110, 2112, 2114, 2116, 2118, 2120

onde se lê/which reads:

Schumann LA

leia-se/ reads up:

Schumann LRMA

p. 2118

onde se lê/which reads:

LA Schumann

leia-se/reads up:

LRMA Schumann 